\title{
Implementation of Diploma Supplement Certificate in Higher Education
}

\author{
Agus Hery Supadmi Irianti, Nurul Aini, Sri Eko Puji Rahayu \\ Universitas Negeri Malang \\ Malang, Indonesia \\ agus.hery.ft@um.ac.id
}

\begin{abstract}
The Rule of the Ministry of Education and Culture number 49 of 2014 on national education standards article 24 verse 5 mentions that the college students who are deemed to graduate, have a right to receive qualifications, degree or appellation, official statements and a companion qualification (diploma supplement). The implementation of diploma supplement in the universities in Indonesia is still very diverse. The purpose of this research is burrowing the information of the implementation of diploma supplement in foreign universities particularly the education of teaching in Indonesia. This research used a descriptive method with survey approach. The results of the study on the implementation of a diploma supplement: the time of implementation of Diploma Supplement Cerificate (SKPI at foreign universities is various. The implementation of it began in $2014 / 2015$. The target of this implementation also varies. There are some universities that apply this certificate to all students and some others apply to the students who need it.The content of diploma supplement certificate is the same , but the mechanisms are different.
\end{abstract}

Keywords - implementation, diploma supplement, higher education

\section{INTRODUCTION}

The ASEAN Economic Community (AEC) in 2015 had a significant and very tight competition of labor. This case is because in the AEC, there is a flow of goods services, investment and skilled labor skilled and free capital among the ASEAN states. The certificate of labor is fought for in this AEC. Labor has a certificate of expertise. For students, the implementation of diploma supplement is to help students and add more values. Diploma supplement shows the recognition of their competence mastery. Diploma supplement that is internationally called a document explanation issued for graduates and containing information of their appreciation called diploma supplement [1].

Since 1999, many countries have adopted diploma supplement as a part of national laws in some countries, but there is no significant development in higher education [2]. In Indonesia, certificate of diploma supplement certificate (SKPI) is stated in the Rule of the Ministry [3]. A supplement project was being done along 2008. This project was organized by enicnaric (the Europe National Information Center- National Academic Recognition Information Center) and enqa ( European National Quality Assurance in college) and funded by a grant of long life learning program of The European
Commission. Students of European States (SES), The Europe University Association (EUA) and European Businessman (businessman federation) joining this project [4].

\section{A. Graduates Problem}

The civilization of technology mainly demands on the in synchronizing a range of information used as a proposition as a thinking framework $\mathrm{s}$ in problem-solving. Characteristic of technology dialectics demands a pattern of thought shifting, meeting the needs of tips, domain and level of competition, and culture to survive [5]. Apart from that, by the implementation of the ASEAN economic community, competition of labor is very tight. Only the labor having a certificate of competency that can in the global market. Nowadays, the main challenge of education in Indonesia is the quality. A survey has been done in Hong Kong showed that the quality of Indonesia education in the Asia Pacific was in the 12th rank under Vietnam, Thailand, and Philippines [6]. The low quality of education slowly brings the effects on labor. As we know in Indonesia there is still many educated unemployed people. Many educated unemployed people namely $50,48 \%$ of them did not finish their study and they were the primary school graduates; $22,83 \%$ of them were junior high school graduates; $14,45 \%$ of them were senior high school graduates; and 12,24 \% of them were the higher education graduates [7]. In addition, in2011, the labor was dominated by the primary school graduates or those who were unfinished the primary school namely 49,50\% of them [8]. Index for are at a position 124 of the 187 the state, under Singapore rank 26; Brunei rank 33; Malaysia rank 61; Thailand rank 103; and the Philippines rank 112 [9]. Such several opinions show that our country is still facing many challenges in competition of labor in the global era. Another opinion that serves as a learner in providing competence to students to work and compete with labors from ASEAN countries. One of them is to provide the competencies that are divided for graduates as outlined in the certificate of diploma supplement (SKPI) [10].

\section{B. Diploma Supplement Certificate (SKPI)}

According to the Rule of the Ministry of Education and Culture [11], Article 1 paragraph 4 on Diploma Supplement Certificate, subsequently it is called diploma supplement, this is a document containing information of academic achievement or qualification of a higher education graduate. Diploma supplement certificate actually helps students and adds more 
benefits because besides the diploma there is still a diploma supplement which shows the acknowledgement of the other competencies. Diploma Supplement is an official statement issued by Higher Education, containing information of academic achievement or qualification of higher education graduate. The qualifications of the graduates are outlined in the form of descriptive narratives stating the learning achievement of the at relevant levels, in a standard format that is easily understood by the general people [11]. The diploma supplement was firstly developed by UNESCO in 1979. Furthermore, in 2003, ENQA stated that the diploma supplement was developed by the European Commission, the Council of Europe and UNESCO aimed to improve the transparency of academic and professional qualifications produced by universities. Furthermore, the diploma graduates who graduated from the college in Europe in 2005 had been completed with DIPLOMA SUPPLEMENT. The students in Europe who graduate from Vocational School or participate in Training Program also receive a kind of diploma supplement called the Euro pass Certificate Supplement.

The employers or the higher education institutions outside Europe are greatly helped by the existence of the Euro pass Certificate Supplement in understanding the workability of the certificate holders or their qualification position in the European Qualification Framework so that it is easily comparable to the qualifications of the others who are from different educational systems. In 1999, 29 countries signed Bologna Declaration for European Higher Education Area (EHEA). Later, the Bologna process has involved a growing number of countries because the EHEA principles are relevant to the needs of education in many countries. Russia joined officially this process in 2003.

Motivation to the process of building EHEA was the successive meetings of HES ministers since the Prague Summit in 2001, and later in Berlin in 2003, Bergen in 2005 London in 2007, Leuven in 2009, Budapest/Viena in 2010, Bucharest in 2012 and 2015 in Yerevan [12].

\section{Purpose and Benefit of Diploma Supplement Certificate}

The purposes of the issuance of Diploma Supplement Certificate according to the [13] Article 2 are (1) the issuance of diploma aims to provide a written proof of learning achievement. (2)The issuance of Competency Certificate aims to provide a written proof of job competence. (3) The issuance of a Professional Certificate aims to provide a written evidence of the ability to practice the profession. Meanwhile, according to the General Director-of Belmawa (2015) mentioned some benefits of diploma supplement for graduates and higher education institutions as well as the other benefits. The benefits for graduates are: (1) they have an additional document showing their ability of work, the mastery of knowledge, and the attitude/moral of a graduate that is more easily understood by the users in and out of the country than by reading transcripts; (2) they have an objective explanation of their achievement and competence; and (3) they can increase employability regardless of the stiffness and type of study program. Meanwhile, the benefits for higher education institutions are: (1) Providing explanations related to graduate qualifications, which are easier to be understood by the community than by reading transcripts; (2) improving the accountability of program implementation by the statement of learning achievement of a transparent program. In the medium to long-term, this supplement diploma will increase the "trust" of the other party and the sustainability of the institution; (3) stating that educational institutions are within the national framework nationally acknowledged and it can be adjusted to the programs at overseas institutions through the respective country qualification framework; (4) improving the understanding of educational qualifications issued in different educational contexts. In addition, the other benefits are: (1) Increasing transparency and acknowledgement, (2) readability and comparison among countries, (3) providing the record of academic career, skills and achievement during studying in the college, (4) emphasizing on the feasibility of working at home and abroad, (5) emphasizing on long-life learning (6) facilitating student's mobility, (7) increasing the work eligibility of graduates in the international work market (8) expediting the acceptance of new students (9) international world.

\section{Implementation of Giving the Diploma Supplement Certificate in Higher Education}

In addition to these two other benefits are: (1) Increasing transparency and recognition, (2) readability and comparison among countries, (3) providing academic career record, skills and achievement during college, (4) emphasizing on the feasibility of working at home and abroad, (5) emphasizing lifelong learning (6) facilitating student mobility, (7) increasing the eligibility of graduate work in the international work market, (8) expediting acceptance of new students , (9) International world

\section{E. Suggestion for Valuable Introductions}

Implementation of giving the diploma supplement certificate in the university is measured by some indicators stated in the form of the following questions: 1) when was diploma supplement started to be implemented, 2) To whom is the implementation of diploma supplement, 3) How to fund the diploma supplement, 4) What are the contents of the diploma supplement 5 ) Is there any involvement of Dudi /the other institutions in supporting the implementation of diploma supplement and 6) How is the mechanism of diploma supplement implementation.

\section{SECTIONS AND CONCLUSIONS}

\section{A. Time of Implementation}

The Diploma Supplement Certificate begins to be implemented depending on the readiness of university organizers. The results of the implementation of the study were different in 2015 and some were beginning in 2016. Implementation is also interpreted as one of the stages in the policy process that brings the society to the expected result [14]. As a part of the policy process, the implementation in the universities is done after the issuance of ministerial regulations related to the supplement diploma, namely the Rule of the Ministry of Education and Culture of the Republic of Indonesia [15], and the Rule of the Ministry of Education and Culture [3], 
[13] gives the detail and deep explanation of the Diploma Supplement Certificate (SKPI).

\section{B. Target of Diploma Supplement Certificate (SKPI).}

The target of the diploma supplement is the student who wants to graduate because the diploma supplement is a certificate which must be issued simultaneously with the diploma certificate received by the students who have finished their course and are eligible for graduation. The research results showed that the target is generally the same i.e. the students, but not all universities provide the diploma supplement certificate to all students who want to graduate. The first target is for all graduates. Meanwhile, in the other universities, the diploma supplement certificate is given only to the students who apply for diploma.

\section{Financing}

The Diploma Supplement Certificate (SKPI).is a document containing the logo and supplementary certificate header, the identity of the supplement diploma holder, the identity of the study program organizer, the learning achievement, and the described competence, and legalization. Printing this document, of course, requires a lot of financing, and therefore the researchers asked the question of financing. According to the small research results, the financing is handled by the universities, so the students are not charged to obtain a diploma supplement.

\section{Content of Diploma Supplement Certificate (SKPI).}

The content of Diploma Supplement Certificate (SKPI) that one should content with Certificate of Accompanying Diploma (SKPI). The results showed that the content set out in a diploma supplement is the same, which includes: logo and header of the diploma supplement, a licentiate supplement identity, the identity of the course. These learning and graduates described the competence and the endorsement. The content set out in a diploma supplement is crucial for college students. The modern education standards in higher education system could help the problems faced by the state. The higher education institution must train the professionals to develop a strong sense of citizenship and affiliation to the country, also admit the freedom, rights, and their privileges [16].

\section{E. Involvement of Outsiders}

Involvement referred to here is involvement industry the industry students. Students who take industrial work practices for 2 months, currently are assessed by the achievement of the numbers assessed from the results of reports and value of the industry in the form of numbers. Should the industry involved issue a letter of competence mastered by the student during the practices? The research results showed that the outside party has not yet been involved to support the needs of Diploma Supplement Certificate (SKPI). During this time D3 (diploma) and S1 (undergraduate) students conduct the industrial work practices in the industry for at least 2 months. However, a judgment formulated is the value in the form of the figure. To help in giving the students' score, this competence should be explained later. Industry should be involved in evaluation.

\section{F. Mechanism of Diploma Supplement (SKPI) Acquisition}

Mechanism of Diploma Supplement Certificate (SKPI) is the mechanism of institutions in issuing the diploma supplement. The research results showed the different mechanism in the issuance of Diploma Supplement Certificate (SKPI). The mechanism in Fig. 1.

\section{CONCLUSION}

This research concludes that the time of the Implementation of Diploma Supplement Certificate (SKPI) in higher education varies. Some universities began to apply it in 2015 and 2016; while there are two target of SKPI namely: all students who will graduate and those who need it. The cost to obtain the Diploma Supplement Certificate (SKPI) is not charged to the student. The contents of the Diploma Supplement Certificate (SKPI) include: Logo and Header of the Diploma Supplement Certificate (SKPI), identity of the holder of that certificate, Identity of Study Program Organizer,

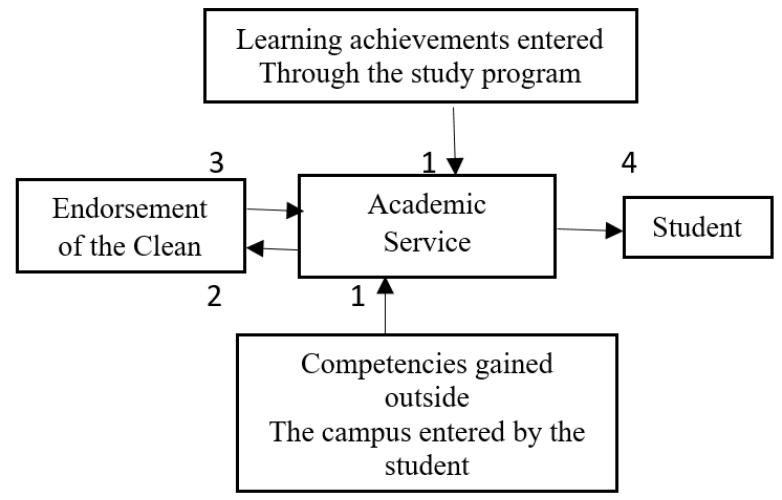

Fig. 1. First Model of Mechanism to Diploma Supplement (SKPI)

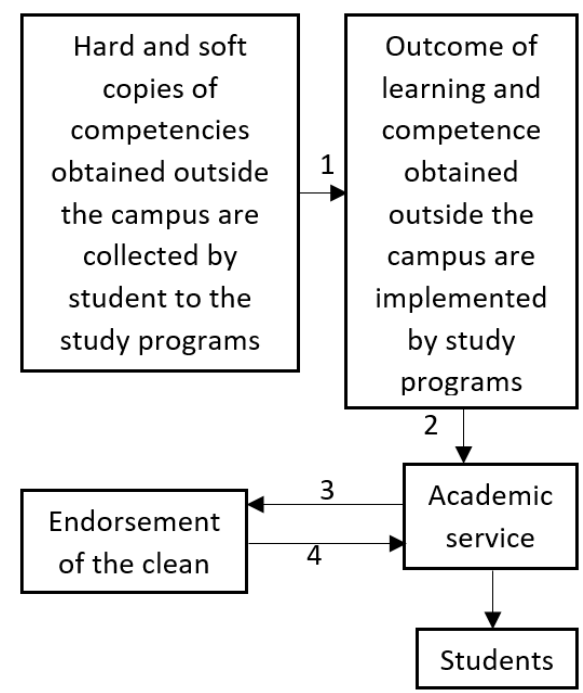

Fig. 2. The second model of the Mechanism to Obtain Diploma Supplement Certificate 
Learning Achievement and described Competence of Graduates. The validation is issued in two languages. The higher education does not involve business world and industrial world in the procedure of issuance of Diploma Supplement Certificate (SKPI); there are two models of the mechanism to obtain the Diploma Supplement Certificate (SKPI).

\section{REFERENCES}

[1] R. James, "Diploma Suplements and Diploma suplemen Model,” 2010. [Online].Available:www.unescobkk.org/.../ppt/Diploma_Supplements_ Mr_Nigel_Palmer.pdf. [Accessed: 19-Jul-2017].

[2] Lisbon (2007) Recognition Convention Committee in 2001 and revised by the Committee in 2007. [Online]. available http://www.coe.int/t/dg4/ highereducation/Recognition./Code\%20of\%20good\%20practice_EN.as p\#TopOfPage, and the UNESCO/OECD Guidelines for Quality Provision in Cross-Border Higher Education adopted in autumn 2005 in the framework of both.

[3]Peraturan Menteri Pendidikan Dan Kebudayaan Republik Indonesia, Tentang Standar Nasional Pendidikan Tinggi. Republik Indonesia, 2014.

[4] A. Guy, C. Bruno, E. Amargan, and H. Emmi, "Study on the Diploma Supplement as seen by its users," 2008.

[5] A. Mukhadis, "Sosok Manusia Indonesia Unggul Dan Berkarakter Dalam Bidang Teknologi Sebagai Tuntutan Hidup Di Era Globalisasi," J. Pendidik. Karakter, vol. 3, no. 2, pp. 115-136, 2013.

[6] H. Wibowo, Kewirausahaan: Suatu Pengantar Membangun Karakter Positif melalui Pembentukan Mindset Wirausaha. Bandung: Widya Padjadjaran, 2011.

[7] R. N. Halim, "Penguatan Lembaga Pendidikan dalam Menumbuhkan Semangat Kewirausahaan," in Makalah Seminar Nasional Pendidikan Islam dan Launching Program Sertifikasi Dosen Perguruan Tinggi Agama Islam 2010, 2010.

[8] M. Nuh, "Zero Loan for Education," Majalah Garuda Indonesia, pp. 70-74, 2012.

[9] J. Dalle, "IMF dan Malapraktik Diplomasi," Kompas, p. 6, 2012.

[10] S. Sarwanto, "Surat Keterangan Pendamping Ijazah bagi Mahasiswa Pendidikan Fisika dan Tantangan Menghadapi Masyarakat Ekonomi Asia," in Prosiding Seminar Nasional Fisika dan Pendidikan Fisika (SNFPF) ke 6 Tahun 2015, 2015, pp. 11-18.

[11] Direktorat Jendral Pembelajaran dan Kemahasiswaan Kementrian Riset, Teknologi dan Pendidikan Tinggi Republik Indonesia. 2015. Surat Keterangan Pendamping Ijazah.

[12] E. Karavaeva and S. Zapryagaev, "Integration of Russian Higher Education System in EHEA," in EIRP Proceedings, 2015, p. 10.

[13] Peraturan Menteri Pendidikan Dan Kebudayaan Republik Indonesia, Ijazah, Sertifikat Kompetensi, dan Sertifikat Profesi Pendidikan Tinggi. Republik Indonesia, 2014.

[14] G. Afan, Politik Indonesia Transisi Demokrasi menuju Demokrasi. Yogyakarta: PustakaPelajar, 2009.

[15] Peraturan Menteri Pendidikan dan Kebudayaan, Penerapan Kerangka Kualifikasi Nasional Indonesia Bidang Pendidikan Tinggi. Republik Indonesia, 2013.

[16] L. Glonti and M. Chitashvili, The Challenge of Bologna: The Nuts and Bolts of Higher Education reform in Georgia, Creating t. Springer, 2006. 